\title{
THE CHARIOT-GROUP OF THE MAUSOLEUM.
}

As the re-arrangement of the sculptures at the British Museum has now reached the Mausoleum Room, the questions as to the restoration of that famous building are naturally brought to the front, and it is to be hoped that the occasion will arouse fresh interest in it in the minds of English friends of art and antiquity.

I do not propose in the present paper to do more than call attention to one point, the composition of the chariot-group which is sometimes supposed to have crowned the edifice. Larger and more general questions I leave. The restorations of Fergusson, Pullan and Petersen, which have been repeated by subsequent writers, ${ }^{\perp}$ all professedly follow the statements of Pliny, and hold the building to have consisted of a pteron standing on a lofty base, and supporting a pvramid on which the chariot-group stood. These writers all gave the Mausoleum the height fixed by Pliny of 140 feet : but recently Dr. Trendelenberg ${ }^{2}$ has called this view in question, maintaining that the full height was only 75 feet, and that the high base is a modern fancy. The question would be worthy of a more careful discussion than it has yet received. Both the older and the newer view are by no means frec from difficulty: but $I$ do not propose in this place to say more on the matter. ${ }^{3}$

It has been usual among restorers of the Mausoleum to place on the summit of the pyramid which crowned the edifice a standing quadriga containing the male and female figures commonly called Mausolus and Artemisia. It is the question whether these figures really belong to the quadriga which I wish briefly to discuss. They were supposed to do so by Sir Charles Newton, though with his usual wise caution he clearly indicates that he regards it as anything but certain. Almost the only subsequent writer who boldly accepts this composition of the chariot-group is Urlichs. ${ }^{4}$ Mr. Murray in his History of Greek Sculpture ${ }^{5}$ (2nd edition) writes of it: 'If these statues, as seems most probable, belonged to the chariot of the

1 See History of Discoveries, Pl. 19 ; Baumeister's Denkmaeler, s. v.; and the histories of sculpture.

${ }^{2}$ Arch. Anzeiger, 1890, p. 105 . Mr. Torr; in calling attention to this paper in the Atheneeum (Feb. 1892), has expressed his agreement with its argument.
3 Recently Mr. Oldfield, in two papers read before the Society of Antiquaries, has proposed quite a new restoration. His views are as yet unpublished.

4 Scopas, p. 189.

ii. 302 . 
pyramid, they would naturally be the work of Pythios.' Stark 6 however had already, nearly thirty years ago, argued that the statues could not belong to the chariot. Wolters ${ }^{7}$ agrees with him, and Overbeck, though with some reserve, inclines to the same opinion. The official Guide of the British Museum (ed. 1890) leaves the question quite open.

I have recently had occasion to consider the arguments on both sides of the question, and have come to the conclusion that Pullan's restoration of the chariot-group cannot be upheld: it seems to me probable for many reasons that the figures of Mausolus and the lady do not belong to the chariot-group which surmounted the Mausoleum.

Let us first consider the ancient evidence, which consists in a passage of Pliny. He says: 'In summo est quadriga marmorea, quam fecit Pythis (v. $l$. Pythius).' Now it seems very unlikely that Pliny would thus speak only of the chariot, if it had contained so important a work as the statue of Mausolus himself. He speaks expressly of a quadriga, and the natural inference is either that the quadriga was empty, or that it contained only a charioteer of no special importance. Such arguments from omission however must never be pressed too far, and cannot be in themselves conclusive.

Secondly it seems in the last degree unlikely that the Greeks would place important portraits in a chariot at a height from the ground, at which they would be practically invisible, at least in detail. Even if we could suppose that visitors could climb the lofty pyramid which supported the chariot, figures standing in it would be quite over their heads and not to be seen. And moreover, in order to support colossal marble figures in the chariot, the bottom of it would have to be made solid with the pedestal, a most awkward as well as an awkward-looking arrangement. A mere marble support in the middle would not be sufficient, for the Greeks were very fond of solidity in their constructions.

These arguments would go to establish the probability that the chariot of Pythius was empty. And what could be more appropriate to a tomb than an empty chariot? The unridden horse, which indicates at once the rank and the death of the hero, commonly makes his appearance on Greek sepulchral reliefs. To our own days the charger of a dead officer is led unridden in his funeral possession. The empty chariot would have the same meaning. I do not mean that an image of Mausolus would necessarily be out of place in the chariot, but merely that its absence would be natural.

From these general considerations let us turn to the examination of the existing marbles. And here there appear to be certain valid reasons for supposing that, whoever may have stood in the chariot, it could scarcely be the statues of Mausolus and the lady which we possess.

The attitude of both these statues is dignified and monumental. Both are clad in full drapery of chiton and overdress. Mausolus stands in a firm attitude, his right hand somewhat raised, in his left hand probably a long sceptre. The lady is a model of finely arranged drapery. What her hands

\footnotetext{
'Philologus, 21, 464.
}

7 Gypsabgïse zu Berlin, i. 427. 
were doing we cannot say; perhaps in one of them she held a patera: they are gently extended.

In order to avoid continuing to call this female figure 'the lady,' I will venture to give her a name. I quite agree with the view which is frequently accepted, and is adopted by Wolters and other authorities, that she must be Artemisia. She is evidently intended to match Mausolus, and was found close to him. In spite of the bad preservation of the head we can trace the ordering of the hair, which clusters round the temples in small formal locks. And Wolters rightly observes that such an arrangement would be very strange in case of a goddess. It is borrowed from life, as we may see from the instance of the stele of Philis, and is probably one of those formal and stately Ionian fashions which lasted longer in Asia Minor than in Greece.

Is it possible then that our Mausolus and Artemisia can have stood in the chariot? It at once occurs to us, that had it been so, one of the two must have been grasping reins and goad, and have worn appropriate dress for driving. The dress of a charioteer is well known, it was a long rather closelyfitting chiton, sometimes gathered closely to the chest, and confined by crossing bands. As examples of chariot-groups we have an almost infinite number of reliefs on the friezes of temples, in dedicatory tab!ets, in metopes like that from Ilium, and on coins. As examples in the round we have no perfect group extant, but we have some evidence of the compositions of the chariot-groups in the western pediment of the Parthenon from the drawings of Carrey. I do not think that I am exaggerating in saying that the whole of this testimony is in the same direction. The charioteer is always showing in his attitude his relation to the horses.

Considering facts like these, which indeed are obvious enough, is it possible to suppose that our two colossal figures stood in a chariot? Neither is clad in charioteer's dress; neither shows the slightest sign of holding the reins or controlling the horses; the dress of both is entirely unaffected by the wind. Possibly it might be fancied that there was a third person, Nike, or some other, present to hold the reins; but for such a theory there is, so far as I know, no ground whatever. Of course, as the chariot was at rest, one would not expect either strain in the person controlling the horses or a violent motion in the drapery; but it seems contrary to the usual customs of Greek art in the case of persons standing in a chariot to give no indication of relation to it or the horses.

Attention has been called to the fact that the figures of Mausolus and Artemisia are of precisely the same marble as are the horses: but this would in any case be natural, and proves nothing. It has further been supposed that the break in the drapery of Mausolus near his left knee may have been made to allow room for the rim, ä $\nu \tau v \xi$, of the chariot. This however cannot be the case. Judging by the size of the wheel, the rim of the chariot if it were of the usual form would be at least as high as the thigh of Mausolus, not his knee : as a matter of fact the break is but $2 \frac{1}{2}$ feet from the plinth, whereas the top of the wheel would be quite a foot higher, 
and the chariot-rim considerably higher still. The break therefore must have had another purpose.

It appears that both of the statues were found in the ncighbourhood of fragments of horses and amid the ruins of the steps of the pyramid. This is no doubt much the strongest argument in favour of their belonging together. But although the fact stated carries weight, yet it does not seem to me to outweigh all that can be said on the other side. The exact findspot of statues has sometimes been a misleading indication. The excavations at Olympia have proved to demonstration what extraordinary chances rule as to the direction falling statues will take or the fate they will meet. Some figures from the Olympian pediments fell almost straight and suffered comparatively little, while other figures close to them in the pediments were hurled to a great distance or shattered into a thousand fragments. In company with the fragments of the horses of the Mausoleum were found not only the statues of Mausolus and Artemisia, but also a variety of heads male and female, fragments of draped figures, and a lion. If the argument from the find-spot were conclusive, it would show that all these stood on the pyramid. It is clear that an earthquake or some violent convulsion had mixed up sculptures from various quarters. In passing I may throw out one question based on the present state of the statues. It is certain that the Mausoleum remained almost uninjured for a very long time, some authorities think as much as 1500 years. ${ }^{8}$ Is it possible that the head of Mausolus which we possess can have been exposed to storm and rain for a third of that time and show so little trace of weather?

These arguments however can only establish a probability, I now come to one which seems to me to go far to establish certainty. In comparison with the wheels and the horses of the chariot the figures of Mausolus and Artemisia are decidedly too small.

I have made many measurements of horses, wheels and riders on friezes, stelae and sculptures in the round. I do not here propose to set forth in detail the results of these measurements, but the general conclusions to which they have led me may be succinctly stated. As the measurements were necessarily only approximate, I will not regard small fractions.

The figure of Mausolus stands 9 feet 10 inches high : that of Artemisia 8 feet 8 inches high.

The chariot-wheel, as restored at the British Museum, has a diameter of 7 feet 7 inches.

The horses as erected have a height from the ground of 11 feet 9 inches to the top of the head; of 8 feet 6 inches to the saddle. ${ }^{9}$

On observing the wheels of chariots on stelae and friezes one finds that their diameter is about half the height of a man, sometimes rather less, sometimes as in the Xanthian frieze slightly more, but never so much as

\footnotetext{
8 Eustathius mentions the Mausoleum as in his time a $\theta a \hat{v} \mu \alpha$ (twelfth century). But it does not follow that it was then intact. It must, however, have remained complete for six or

seven centuries.

9 The horses I measured; the other figures are taken from official statements.
} 
three-fourths of that height. Yet this last is the proportion between the diameter of the Mausoleum chariot-wheel and the height of Mausolus.

As regards the proportionate height of horse and man, the general rule in Greek sculpture of the best period seems to be that the standing horse and the man are of about equal height; while the length of a horse's body is about three-fourths of that height. These proportions hold in the Parthenon and Mausoleum friezes; but of course this evidence cannot be insisted on, since in any case the isocephalic law would require the heads of horses and men to be about on a level. If however we turn to sepulchral stelae and other reliefs where this law does not prevail, we find the same scale of proportion usually to hold. And it is shown also in the few cases in which we possess horsemen sculptured in the round. Thus if the horseman of the Locrian pediment ${ }^{10}$ be restored, it will be found that his height is one-third greater than the length of his horse's body, so that if he stood beside the horse the tops of their heads would be level.

We have however the good fortune to possess several equestrian figures in the round sculptured by the very artists who worked on the Mausoleum. The figures of an Amazon and Nereids from Epidaurus, ${ }^{11}$ apparently made from the designs of Timotheus, are of about the same height in proportion to their horses as in the Locrian rider : that is, the rider and the horse are of about equal height.

But perhaps the best instance which can be cited is the Persian horseman from the Mausoleum. This rider, to judge from the length of his thigh (about 32 inches), would if standing be between 9 feet and 9 feet 6 inches high. His horse is just about 7 feet long, and so would be just as tall as the rider, if both stood complete. It thus seems to be the rule in good Greek art that the tops of the heads of a standing horse and of a standing man should be about on a level. Yet the head of Mausolus is 2 feet lower than that of the Mausoleum chariot-horse, while the head of Artemisia barely reaches up to his saddle.

Perhaps the easiest way to convince one's eyes of the disproportion between Mausolus and the chariot-horse is to compare him with this Persian rider who stands in the same room with him at the British Museum. This rider was nearly as tall as Mausolus, and decidedly taller than Artemisia, but the horse he bestrides looks like a little pony beside the huge chariot-horses, while in style it is incomparably superior.

An anonymous writer to the Athenaenm ${ }^{12}$ has tried to remove the force of arguments such as these used by me on a previous occasion. In the first place he maintains that the proportion of the height of the head of Mausolus to the length of the head of the chariot-horse is the same as is found in the case of men and horses in the Parthenon pediment and in nature. I do not controvert his statement; but he has overlooked the further fact that the head of the Mausoleum chariot-horse is quite abnormally short. Its length

10 Röm. Mittheil. v. Pl. 9.

1.: Mar. 12, 1892 .

11 Cavradias, Fouilles d' Epidaure, Pl. 9. 
in proportion to the height of the horse is only 29 , whereas the length of head in proportion to height is in the Parthenon frieze about 34 or 35 : on the other hand the head of Mausolus is unusually large in proportion to the total height of the statue. Thus to measure only the heads is misleading; the thing to be considered is the relative heights of horse and man; and it could scarcely be maintained that if the head of the horse of Helios in the Parthenon pediment were joined to a proportionate body it would stand as much higher than the head of the Theseus standing as does the head of the Mausoleum chariot-horse above that of Mausolus.

The same writer observes that 'the horses of Asia Minor were of a much larger breed than those of Greece proper.' Whether this were the case or not, the instances of the Persian rider and of the frieze prove that this larger breed did not influence the art, at bottom Attic, of the Mausoleum. Finally, it might be said that chariot-horses would be taller than ridinghorses. But in the numerous instances of both which $I$ have examined in Greek art $I$ have found no difference in size. The chariot-horse was selected not like a modern carriage-horse for drawing-power, but for swiftness and lightness.

It thus seems impossible to escape the conclusion that the size of the Mausoleum chariot-horses, as well as of the wheel, is quite out of proportion to that of the figures of Mausolus and Artemisia.

And this argument gains on reflection. The only chance that the charioteers would be seen properly from below would lie in their being tall in proportion to the chariot. Our two statues would be in such a position simply invisible. This does not strike one strongly in looking at the designs of Pullan and Urlichs and Petersen, because they are ail sections and give no notion of the whole as it would look from below. But it would clearly appear if a model were made to scale. Mausolus in the chariot would stand, according to Mr. Pullan, less than 14 feet high, and if he were placed on a lofty pedestal with four gigantic horses each nearly 12 feet high in front of him, no one from below would see even his head from the front, and the side view would scarcely be more satisfactory. And this may in fact be judged from a consideration of the figures as now arranged in the British Museum. If we fill in in imagination two additional horses between the two flanking ones, of which alone fragments remain, we shall observe that from the front Mausolus and Artemisia would be almost invisible. The chin of Mausolus and the top of the head of Artemisia would only have been visible over the horses' heads from below, the ground being level, at a distance of about 1000 feet supposing that the building was 75 feet high, and at a distance of quite a third of a mile supposing that it was 140 feet high.

Sir Charles Newton has succeeded in pointing out some merits in the great chariot-horses. But they certainly convey an unpleasant impression; they are heavy and rough and not worked in detail. They may well pass as the work of Pythius, who seems to have been not a sculptor but an architect. $\mathrm{He}$ is said to have planned not only the Mausoleum but also the temple of 
Athena at Priene. ${ }^{13} \quad \mathrm{He}$ was no doubt instructed to make a great decorative group which would suit the building and pass muster at a distance. The figures of Mausolus and Artemisia on the other hand are noble and pleasing monumental works, not specially refined but yet well suited for near inspection. The shoe of Mausolus has often been admired, and it seems probable that it was meant to be seen.

I conceive then that these two admirable portraits stood somewhere within the building. Where they stood I am not prepared to say. Stark thought that they stood in niches; but Overbeck thinks this unlikely, because the backs are too carefully finished. The fact is that the arrangement of the statues from the Mausoleum is an unsolved and perhaps an insoluble problem. Part of a standing male figure on the same scale as Mausolus was found; and part of a colossal seated figure. How many figures may have disappeared we know not.

It seems to me that the noble figures of Mausolus and his wife have been somewhat undervalued becaused it was supposed that they were the work of Pythius, and because they were brought into connexion with the clumsy horses. But we know that at least four of the ablest artists of Greece, Scopas, Bryaxis, Leochares, and Timotheus, were employed on the Mausoleum in rivalry one of the other, and it seems impossible that they can have left so important work as that of these great statues to inferior artists. To which of these four sculptors we may best assign the statues I do not venture to decide; but the problem thus set before us is certainly attractive, and the chances of its solution are rapidly increasing, since we now possess sculptures coming either from the hand or the school of each of the four. In a paper recently published in Dutch, M. Jan Six, agreeing as he informs me with my argument as published in the Times ${ }^{14}$ against the assignment of the portrait-statues to the quadriga, boldly names Bryaxis, probably a Carian, as the author of the portrait of Mausolus. But I think that the question needs a more careful investigation, before it can be regarded as settled.

\section{Percy Gardner.}

13 Brunn, Grie. Künstler, ii. 376. According to Rayet, Études d'archéologie, p. 105, Pythis or Pythius was the greatest of the Ionic architects, and skilled in all branches of art and seience.

14 Feb. 24, 1892. 